\title{
Comparative effect of a previous 150-MPa treatment on the quality loss of frozen hake stored at different temperatures
}

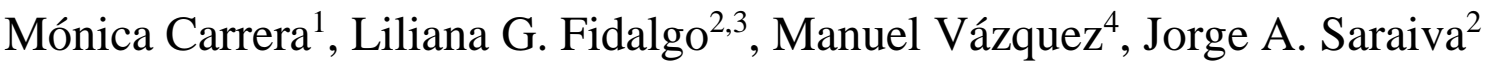 \\ and Santiago P. Aubourg, ${ }^{1, *}$
}

${ }^{1}$ Department of Food Technology, Marine Research Institute (CSIC), 36208-Vigo, Spain.

2 QOPNA \& LAQV-REQUIMTE, Department of Chemistry, University of Aveiro, 3810-193 Aveiro, Portugal.

3 Present address: Department of Applied Technologies and Sciences, School of Agriculture, Polytechnic Institute of Beja, 7800-295, Beja, Portugal.

This article has been accepted for publication and undergone full peer review but has not been through the copyediting, typesetting, pagination and proofreading process which may lead to differences between this version and the Version of Record. Please cite this article as doi: $10.1002 /$ jsfa.10465 
${ }^{4}$ Department of Analytical Chemistry, Faculty of Veterinary Science, University of Santiago de Compostela, 27002-Lugo, Spain.

* Correspondent: saubourg@iim.csic.es; +34986292762 (fax), +34986231930 (phone). ORCID number: 0000-0002-3136-8137. 


\section{ABSTRACT}

BACKGROUND: This study was addressed to the quality loss of European hake (Merluccius merluccius) during frozen storage. Its objective was to comparatively analyse the effect of a previous high-pressure processing (HPP) (150 MPa for 2 min) when different storage temperatures $\left(-10,-18\right.$ and $\left.-30^{\circ} \mathrm{C}\right)$ were employed.

RESULTS: Most chemical quality indices (trimethylamine, TMA; dimethylamine, DMA, formaldehyde, FA; free fatty acids, FFA) provided a marked content increase with freezing and frozen storage time, values being higher by increasing the storage temperature. Previous HPP led to an inhibitory $(p<0.05)$ effect on the TMA, DMA, FA and FFA formation in frozen fish kept at -10 and $-18{ }^{\circ} \mathrm{C}$, the preservative effect being higher at the highest temperature tested; however, in agreement to the low damage development, no effect could not be proved on samples stored at $-30{ }^{\circ} \mathrm{C}$. Concerning lipid oxidation, peroxides formation was found low, although a slight increasing effect $(p<0.05)$ was implied in fish corresponding to all temperatures as a result of the previous HPP; furthermore, an inhibitory effect $(p<0.05)$ on fluorescent compounds formation (tertiary lipid oxidation) was evident after freezing and at month 9 for $-10{ }^{\circ} \mathrm{C}$ samples.

CONCLUSION: It is concluded that a 150-MPa high-pressure treatment may inhibit the formation of degradative molecules such as DMA, FA, TMA and FFA during the frozen storage at $-18{ }^{\circ} \mathrm{C}$ (maximum recommended) and $-10{ }^{\circ} \mathrm{C}$. However, results have indicated that lowering the storage temperature showed to be more effective than the current HPP (150 MPa for 2 min). 
Running title: Frozen hake quality and previous high-pressure processing

Keywords: High-pressure processing; Merluccius merluccius; frozen storage; volatile amines; formaldehyde; lipid hydrolysis.

\section{INTRODUCTION}

High-pressure processing (HPP) is currently accepted as an attractive technology for food preservation. Its effects have proved to be uniformly and nearly instantaneously distributed throughout the food sample and consequently, independent of food geometry and equipment size. ${ }^{1,2}$ Related to marine foods, main profitable advantages of HPP have addressed the fact that microbial and parasite populations as well as endogenous enzymes have shown to be inactivated. ${ }^{3-5}$

Fish species belonging to the Gadoid group (hake, cod, haddock, whiting, etc.) can provide highly important commercial products in agreement to their great consumer acceptance and their large catches in most West-European countries. As for most frozen lean fish species, protein denaturation has been signalled as a major problem, thus leading to marked off-odour development and texture losses. ${ }^{6,7}$ Different damage mechanisms have been proposed to explain such protein denaturation: a) protein interaction with deteriorative molecules such as formaldehyde (FA) and oxidised and hydrolysed lipids, b) protein dehydration during freezing due to the formation of ice crystals, and c) protein micro-environment modification as a result of the salts concentration in the surrounding liquid phase. ${ }^{8,9}$

Among Gadoid species, European hake (Merluccius merluccius) represents an important overall catching and consumption as a result of its excellent organoleptic 
properties. Hake frozen storage has provided a profitable way to enlarge its consumption while retaining its quality. However, when large storage periods are needed or convenient temperatures are not maintained (i.e., breakdown of the cold chain) different kinds of damage events have shown to be produced; among them, structural changes ${ }^{10}$ and formation of FA and volatile amines, ${ }^{11}$ free amino acids ${ }^{12}$ and lipid damage compounds ${ }^{13}$ have proved a marked effect on quality loss.

Among the different advanced technologies, HPP has been applied in order to enhance quality of hake products. Thus, a preservative effect on physicochemical properties of isolated sarcoplasmic ${ }^{14}$ and myofibrillar ${ }^{15}$ proteins was proved. However, Carrera et al. ${ }^{16}$ analysed the effects of HPP on muscle proteome by using bottom-up proteomics strategies; as a result, the employment of a high-pressure level $\geq 430 \mathrm{MPa}$ led to a marked denaturation and aggregation of most enzymes. Furthermore, inhibition of Anisakis simplex L3 presence in fresh hake was achieved by Vidacek et al. ${ }^{17}$ Concerning frozen (5 months at $-10^{\circ} \mathrm{C}$ ) hake, an inhibitory effect on the formation of deteriorative compounds such as volatile amines, FA and free fatty acids (FFA) was observed by Vázquez et al. ${ }^{18}$ if previously treated under HPP (150-450 MPa for 2 min). Under the same high-pressure and frozen storage conditions, ${ }^{19}$ the analysis of mechanical properties and visual appearance of frozen hake showed that the employment of a low-pressure level (i.e., $150 \mathrm{MPa}$ ) would adequately retain sensory and physical properties when compared to fresh fish.

This study was addressed to the quality loss of European hake (Merluccius merluccius) during frozen storage. Its objective was to comparatively analyse the effect 
of a previous HPP (150 MPa for 2 min) when different storage temperatures were employed, a special stress being given to the maximum permitted temperature (i.e., -18 ${ }^{\circ} \mathrm{C}$ ). For it, the formation of degradative molecules (volatile amines, FA, FFA and lipid oxidation compounds) related to quality loss was comparatively analysed.

\section{MATERIALS AND METHODS}

\section{Raw fish, processing, storage and sampling}

European hake (186 individuals) were caught near the Galician Atlantic coast (North-Western Spain) and transported under ice to the laboratory. The length and weight of the specimens ranged 28.5-31.5 cm and 185-215 g, respectively. Upon arrival to the laboratory, six individuals were separated and divided into three groups (two specimens per group) that were analysed independently $(n=3)$ as initial fresh fish.

The remaining fish individuals were placed in flexible polyethylene bags (30 bags; six individuals per bag), vacuum-sealed at 150 mbar (Vacuum Packaging Machine Culinary, Albipack, Águeda, Portugal) and divided into two groups (15 bags in each group). Bags corresponding to one of such groups were kept at $-40{ }^{\circ} \mathrm{C}$ for $48 \mathrm{~h}$ and then divided into three batches ( 5 bags in each batch) that were stored, respectively, at $10,-18$ and $-30{ }^{\circ} \mathrm{C}$. Such batches were considered as control fish, respectively, for the three storage temperatures.

Fish corresponding to the other group were submitted to HPP (150 MPa for 2 min) in a 55-L high pressure unit (WAVE 6000/55 HT; NC Hiperbaric, Burgos, Spain). For it, water was applied as the pressurising medium at $3 \mathrm{MPa} \mathrm{s}^{-1}$ yielding $54 \mathrm{~s}$ as the 
come up time, decompression time being less than $3 \mathrm{~s}$. Cold pressurising water was used to maintain temperature conditions during high-pressure treatment at $18.8-21.0{ }^{\circ} \mathrm{C}$, the fish temperature being in the $9-10{ }^{\circ} \mathrm{C}$ range. After $\mathrm{HPP}$, bags were kept at $-40{ }^{\circ} \mathrm{C}$ for $48 \mathrm{~h}$ and then divided into three batches (5 bags in each batch) that were stored, respectively, at $-10,-18$ and $-30{ }^{\circ} \mathrm{C}$.

For both groups (high-pressure treated and control), sampling was carried out at month 0 (after freezing; $48 \mathrm{~h}$ at $-40{ }^{\circ} \mathrm{C}$ ) and after 3, 6, 9 and 12 months of frozen storage, except for the study at $-10{ }^{\circ} \mathrm{C}$ that was stopped at month 9 due to the high level of deterioration. Three replicates $(n=3)$ for each technological condition were considered and analysed independently at each sampling time. Each analysis was carried out on the corresponding extract from the fish white muscle pooled from two fish individuals. All solvents and chemical reagents used in the current study were of reagent grade (Merck, Darmstadt, Germany).

\section{Volatile amines formation}

Trimethylamine (TMA)-nitrogen (TMA-N) values were determined using the picrate spectrophotometric $(410 \mathrm{~nm})$ method (Beckman Coulter DU 640 spectrophotometer), as previously described by Tozawa et al. ${ }^{20}$ This method involved the preparation of a $50 \mathrm{~g} \cdot \mathrm{L}^{-1}$ trichloroacetic acid (TCA) extract of fish white muscle (10 g in $25 \mathrm{~mL}$ TCA). Results were calculated as mg TMA-N $\cdot \mathrm{kg}^{-1}$ muscle.

Dimethylamine (DMA)-nitrogen (DMA-N) content was determined in the $50 \mathrm{~g}$ $\mathrm{L}^{-1}$ TCA extract of fish white muscle $(10 \mathrm{~g}$ in $25 \mathrm{~mL}$ TCA $)$ using the 
spectrophotometric (431 nm) method of Dowden. ${ }^{21}$ This method is based on the specific complex formation from secondary amines in the presence of a copper salt and carbon sulphur in basic medium. Results were calculated as mg DMA-N $\cdot \mathrm{kg}^{-1}$ muscle.

\section{Formaldehyde assessment}

Extraction of FA from fish muscle was carried out according to Rey-Mansilla et al. ${ }^{11}$ FA content was determined by the spectrophotometric $(412 \mathrm{~nm})$ method of Nash ${ }^{22}$ and expressed as $\mathrm{mg} \cdot \mathrm{kg}^{-1}$ muscle.

\section{Lipid damage analyses}

Lipids were extracted from the hake white muscle by the Bligh and $\mathrm{Dyer}^{23}$ method, which employs a single-phase solubilisation of the lipids using a chloroformmethanol (1:1) mixture. The results were calculated as g lipid $\cdot \mathrm{kg}^{-1}$ muscle.

FFA content was determined using the lipid extract of the fish muscle by the Lowry and Tinsley ${ }^{24}$ method, which is based on complex formation with cupric acetatepyridine followed by spectrophotometric $(715 \mathrm{~nm})$ assessment. The results were expressed as $\mathrm{mg} F F A \cdot \mathrm{kg}^{-1}$ muscle.

Peroxide value (PV) was determined spectrophotometrically (520 nm) on the lipid extract by peroxide reduction with ferric thiocyanate, according to Chapman and McKay. ${ }^{25}$ The results were calculated as meq. active oxygen $\cdot \mathrm{kg}^{-1}$ lipids.

The formation of fluorescent compounds (Fluorimeter LS 45; Perkin Elmer España; Tres Cantos, Madrid, Spain) was determined in the aqueous phase resulting 
from the lipid extraction of the fish muscle ${ }^{23}$ by measurements at 393/463 and 327/415 nm as described previously. ${ }^{26}$ The relative fluorescence (RF) was calculated as follows: $\mathrm{RF}=F / F_{\text {st }}$, where $F$ is the fluorescence measured at each excitation/emission wavelength pair and $F_{\text {st }}$ is the fluorescence intensity of a quinine sulphate solution (1 $\mu \mathrm{g} \cdot \mathrm{mL}^{-1}$ in $0.05 \mathrm{M} \mathrm{H}_{2} \mathrm{SO}_{4}$ ) at the corresponding wavelength pair. Results were calculated as the fluorescence ratio (FR), which was calculated as the ratio between the

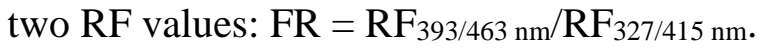

\section{$\underline{\text { Statistical analysis }}$}

Data obtained from all chemical analyses were subjected to the ANOVA method to explore differences resulting from the effect of the previous HPP. The comparison of means was performed using the least-squares difference (LSD) method. In all cases, analyses were carried out using the PASW Statistics 18 software for Windows (SPSS Inc., Chicago, IL, USA); differences among batches were considered significant for a confidence interval at the $95 \%$ level $(p<0.05)$ in all cases.

\section{RESULTS AND DISCUSSION}

\section{TMA formation}

A marked TMA formation resulting from the freezing step was observed in high-pressure treated and control samples (Table 1). Furthermore, results concerning the TMA formation throughout storage can be considered as very different depending on the temperature considered. However, values obtained remained in all cases below the 
threshold value for this fish species (50 mg TMA-N kg-1 muscle). ${ }^{27}$ Thus, a strong formation with storage time could be observed in samples stored at $-10{ }^{\circ} \mathrm{C}$, average values being lower in those that were previously submitted to HPP; such differences were found significant $(p<0.05)$ at months 3 and 9 . In the case of taking into account fish stored at -18 and $-30{ }^{\circ} \mathrm{C}$, a moderate increase with storage time was implied in both high-pressure treated and control samples. Concerning $-18{ }^{\circ} \mathrm{C}$ samples (maximum recommended storage condition), an inhibitory effect on TMA formation was implied as a result of previous HPP; thus, lower average values were obtained in high-pressure treated fish throughout the whole study, differences being significant $(p<0.05)$ at months 3, 6 and 12. Samples stored at $-30^{\circ} \mathrm{C}$ did not provide significant differences ( $p$ $>0.05)$ as a result of HPP, although higher average values were obtained in the previously treated batch (3-12-month period).

This inhibitory effect on TMA formation at $-10{ }^{\circ} \mathrm{C}$ agrees with previous research carried out on frozen hake (2.5 months at $-10^{\circ} \mathrm{C}$ ) previously submitted to HPP (150 MPa for 2 min). ${ }^{18}$ Previous research on frozen fatty fish species (sardine, Sardina pilchardus; mackerel, Scomber scombrus) showed an inhibitory effect of previous HPP (125-200 MPa for 0 min) on TMA formation only after the freezing step, ${ }^{28,29}$ while no effect could be observed during a further frozen storage ( 9 months at $-18{ }^{\circ} \mathrm{C}$ ). Interestingly, an inhibitory effect of previous HPP on TMA formation in other kinds of marine products has been described. This accounts for refrigerated (28 d at $\left.4{ }^{\circ} \mathrm{C}\right)^{30}$ and semi-dried ${ }^{31}$ squid (T. pacificus) after a previous HPP (500 MPa for 0-10 min) as well 
as for refrigerated $\left(7 \mathrm{~d}\right.$ at $\left.4{ }^{\circ} \mathrm{C}\right)$ and frozen $\left(50 \mathrm{~d}\right.$ at -5 and $\left.-20{ }^{\circ} \mathrm{C}\right)$ minced cod (Gadus morhua) after previous HPP (193 MPa at $\left.-20^{\circ} \mathrm{C}\right) .^{32}$

\section{Formation of DMA and FA}

DMA content showed a marked increase after the freezing step in both treated and control samples (Figure 1). Then, a progressive increase could be observed throughout the frozen storage period in both kinds of samples stored at $-10{ }^{\circ} \mathrm{C}$; lower average values were observed in treated fish, although significant differences $(p>0.05)$ were not observed. Contrary, treated and untreated fish stored under -18 and $-30{ }^{\circ} \mathrm{C}$ conditions revealed a DMA content decrease in the 0-3-month period that was followed by a moderate increase in samples stored at $-18{ }^{\circ} \mathrm{C}$, while no further increase could be detected in fish stored at $-30{ }^{\circ} \mathrm{C}$. Previous HPP led to lower average values in samples stored under $-18{ }^{\circ} \mathrm{C}$ condition, although significant differences $(p<0.05)$ could only be detected at month 9. In agreement to the negligible DMA formation at $-30{ }^{\circ} \mathrm{C}$ condition, no significant $(p>0.05)$ effect could be demonstrated for the previous pressure treatment. Thus, lowering the storage temperature has shown to be more effective than the current HPP (150 MPa for 2 min) for reducing the DMA content.

FA content analysis provided a general progressive increase throughout the frozen storage (Figure 2). This increase was found greater by increasing the storage temperature. Comparison between both kinds of samples showed lower average values in most cases in previously treated fish corresponding to -10 and $-18{ }^{\circ} \mathrm{C}$; however, differences were not found significant $(p>0.05)$. A definite effect could not be implied 
in samples corresponding to $-30{ }^{\circ} \mathrm{C}$, although a higher value $(p<0.05)$ for HPP-treated samples was observed at month 9 revealing similar values to control fish at the end of the experiment. As for the DMA formation, lowering the storage temperature has shown to be more effective than the current HPP for reducing the FA content.

Previous research has provided information related to the inhibitory effect that a previous HPP may have on the formation of these two molecules during the frozen storage. Thus, Vázquez et al. ${ }^{18}$ showed a marked inhibition of DMA and FA presence in frozen (5 months at $-10{ }^{\circ} \mathrm{C}$ ) hake if previously submitted to high-pressure conditions (150-450 MPa for $2 \mathrm{~min}$ ); this inhibitory effect showed to be lower when applying the lowest pressure level (i.e., $150 \mathrm{MPa}$ ) in agreement to current results. Furthermore, DMA formation was inhibited in other marine products such as minced cod (G. morhua) meat (HPP of $193 \mathrm{MPa}$ at $-20{ }^{\circ} \mathrm{C}$ followed by storage at $4,-5$ and $-20{ }^{\circ} \mathrm{C}$ ), ${ }^{32}$ refrigerated squid (T. pacificus) $)^{30}$ and semi-dried ${ }^{31}$ squid (T. pacificus) (HPP of $500 \mathrm{MPa}$ for 0-10 min followed by storage at $4{ }^{\circ} \mathrm{C}$ for $28 \mathrm{~d}$ ). Concerning FA formation in a frozen fish product, its content showed to be notably reduced in frozen (50 d at -5 and $-20{ }^{\circ} \mathrm{C}$ ) minced cod (G. morhua) meat if a previous HPP (193 MPa at $-20{ }^{\circ} \mathrm{C}$ ) was applied. ${ }^{32}$

\section{Lipid hydrolysis development}

The freezing step led to a marked FFA formation in both treated and non-treated samples (Figure 3). Throughout the frozen storage, a strong lipid hydrolysis development was observed in all kinds of samples, this development being stronger by increasing the storage temperature. Concerning the effect of the previous HPP, lower 
average values were obtained at all sampling times and at all storage temperatures in batches corresponding to the high-pressure treated fish. This inhibitory effect was found to be more relevant by increasing the storage temperature tested. Thus, differences were found significant $(p<0.05)$ at $-10{ }^{\circ} \mathrm{C}\left(3-9\right.$-month period) and at $-18{ }^{\circ} \mathrm{C}$ storage (months 6 and 12) conditions. Contrary, no significant differences $(p>0.05)$ could be obtained when taking into account samples stored at $-30^{\circ} \mathrm{C}$.

Lipid hydrolysis development has been recognised as a most important event during the frozen storage of a lean fish species. ${ }^{13,26}$ Indeed, an increasing effect on protein denaturation and aggregation during fish frozen storage has been mentioned. ${ }^{6,12}$ This degradative pathway has been signalled as the result of an increased hydrolytic endogenous enzyme (lipases, phospholipases) activity during the frozen storage. ${ }^{33}$ Recent research related to the effect of HPP on lipid hydrolysis development can be pointed out. Thus, FFA content was found to be greatly reduced in frozen (5 months at $-10{ }^{\circ} \mathrm{C}$ ) hake if previously submitted to HPP (150-450 MPa for $\left.2 \mathrm{~min}\right),{ }^{18}$ this effect increasing with the pressure level applied. In agreement with the current results, an inhibitory effect was observed when applying a 150-MPa treatment. This inhibitory effect on FFA formation was also observed during the frozen storage of fatty fish species such as Atlantic mackerel (S. scombrus) (125-200 MPa for 0 min followed by 9 months at $\left.-18{ }^{\circ} \mathrm{C}\right),{ }^{28}$ Atlantic horse mackerel (Trachurus trachurus) (150-450 MPa for 0-5 min followed by 3 months at $\left.-10^{\circ} \mathrm{C}\right)^{34}$ and sardine (S. pilchardus) (125-200 MPa for 0 min followed by 9 months at $\left.-18^{\circ} \mathrm{C}\right) .{ }^{29}$ 


\section{Lipid oxidation development}

In all cases, peroxides formation can be considered as low, all values remaining below a score of 8.5 (Table 2). A progressive formation of primary oxidation compounds was implied in most cases in fish corresponding to $-10{ }^{\circ} \mathrm{C}$ storage throughout the freezing and frozen storage steps; however, a definite trend could not be concluded in batches corresponding to the two other temperatures throughout storage. Concerning the effect of previous HPP, some higher values $(p<0.05)$ were obtained in pressurised fish when considering batches corresponding to $-10{ }^{\circ} \mathrm{C}$ (month 6), $-18{ }^{\circ} \mathrm{C}$ (9-12-month period) and $-30^{\circ} \mathrm{C}$ (month 9).

Taking into account the value observed for the initial fresh fish, the FR showed scarce increases throughout the frozen storage at all temperature conditions (Table 3). After the freezing step, a lower $(p<0.05)$ FR value was observed in samples previously submitted to pressure processing. However, a definite trend could not be concluded throughout the frozen storage period at any of the storage temperatures tested; nevertheless, an inhibitory effect on fluorescent compounds formation was observed at the end of the experiment in samples corresponding to $-10{ }^{\circ} \mathrm{C}$ storage.

Data on PV and FR indicate that lipid oxidation development has not been especially important in the current process (i.e., frozen storage of a lean fish species; lipid content of current hake muscle: $4.70-5.55 \mathrm{~g} \mathrm{~kg}^{-1}$ muscle), so that a relevant effect of previous HPP could not be concluded. Contrary, a marked development of lipid oxidation (PV and FR determinations) was observed in hake stored at -10 and $-30{ }^{\circ} \mathrm{C}^{13}$ as well as in other Gadoid fish species (cod, Gadus morhua, and haddock, 
Melanogrammus aeglefinus). ${ }^{26}$ Also contrary to the current study, Vázquez et al. ${ }^{18}$ observed a marked lipid oxidation development (determination of PV and FR) in frozen (5 months at $-10^{\circ} \mathrm{C}$ ) hake; furthermore, a previous HPP (150-450 MPa for 2 min) inhibited the formation of tertiary compounds (FR assessment) and maintained the content of primary ones (PV determination). No effect on TBARS (secondary lipid oxidation compounds) content was observed by Chevalier et al. ${ }^{35}$ in frozen (75 d at -20 ${ }^{\circ} \mathrm{C}$ ) turbot (Scophthalmus maximus) fillets by applying pressure-shift freezing at 140 MPa. Concerning fatty fish species, a marked lipid oxidation development was observed in mackerel (S. scombrus $)^{28}$ and sardine $(S \text {. pilchardus })^{29}$ during frozen storage (9 months at $-18{ }^{\circ} \mathrm{C}$ ); in both studies, an inhibitory effect on this development (i.e., FR value) was observed as a result of applying a previous HPP (125-200 MPa for 0 min).

\section{CONCLUSIONS}

A high-pressure treatment (150 MPa for 2 min) was tested to comparatively analyse its effect on the quality of frozen hake stored at different temperatures $(-10,-18$ and $-30{ }^{\circ} \mathrm{C}$ ). It could be concluded that such previous treatment can partially slow down the development of different damage pathways resulting from relatively high storage temperatures, often present during breakdown of the cold chain throughout any of the commercialisation steps required. On the basis of the average values obtained, formation of degradative molecules such as DMA, FA, FFA and TMA could be inhibited partially in fish muscle when stored at the maximum recommended temperature $\left(-18{ }^{\circ} \mathrm{C}\right)$ and at a relatively high-temperature $\left(-10{ }^{\circ} \mathrm{C}\right)$ condition; 
interestingly, such molecules are recognised as being responsible for strong sensory and nutritional quality losses during Gadoid species trading. In agreement to the negligible damage development at $-30{ }^{\circ} \mathrm{C}$ condition, no effect could be demonstrated for the previous pressure treatment. Current results have also shown that lowering the storage temperature showed to be more effective than the current HPP, this including a relatively low pressure condition. However, quality performances obtained by the current previous high-pressure treatment would justify a further research with commercial overview. 


\section{ACKNOWLEDGMENTS}

The authors thank Mr. Marcos Trigo and Mr. Juan J. Fariñas for their excellent technical assistance. The work was supported by the Consejo Superior de Investigaciones Científicas (CSIC) (Spain) through the Research Project 2017-70E032, by Fundação para a Ciência e a Tecnologia (FCT Portugal), European Union, QRN, FEDER, COMPETE through founding of the Organic Chemistry Research Unit (QOPNA) (project PEst-C/QUI/UI0062/2013; FCOMP-01-0124-FEDER-037296), and by Formula Grants no. 2011-31200-06041 and 2012-31200-06041 from the USDA National Institute of Food and Agriculture. 


\section{REFERENCES}

1 Torres JA and Velázquez G, Commercial opportunities and research challenges in the high pressure processing of foods. J Food Eng 67: 95-112 (2005).

2 Bermúdez-Aguirre D and Barbosa-Cánovas G, An update on high hydrostatic pressure, from the laboratory to industrial applications. Food Eng Rev 3: 44-61 (2011).

3 Molina-García AD and Sanz PD, Anisakis simplex larva killed by high-hydrostaticpressure processing. J Food Prot 65: 383-388 (2002).

4 Chéret R, Hernández-Andrés A, Delbarre-Ladrat C, de Lamballerie M and VérrezBagnis V, Proteins and proteolytic activity changes during refrigerated storage in sea bass (Dicentrarchus labrax) muscle after high-pressure treatment. Eur Food Res Technol 222: 527-535 (2006).

5 Aubourg SP, Impact of high-pressure processing on chemical constituents and nutritional properties in aquatic foods: A review. Int J Food Sci Technol 53: 873-891 (2018).

6 Mackie I, The effect of freezing on flesh proteins. Food Rev Intern 9: 575-610 (1993).

7 Herrero A, Huiodobro A, Careche M, Devolpment of a Quality Index method for frozen hake (Merluccius capensis and Merluccius paradoxus). J Food Sci 68: 1086-1092 (2003).

8 Sikorski Z, Kolakowska A, Changes in protein in frozen stored fish, in: Seafood proteins, ed. by Sikorski Z, Sun Pan B and Shahidi F. Chapman and Hall, New York, USA, pp. 99-112 (1994). 
9 Sotelo C and Rehbein H, TMAO-degrading enzymes, in: Seafood enzymes. Utilization and influence on postharvest seafood quality, ed. by Haard N and Simpson B. Marcel Dekker, Inc, New York, USA, pp. 167-190 (2000).

10 Careche M, Herrero A, Rodríguez-Casado A, Del Mazo $\mathrm{M}^{\mathrm{a}} \mathrm{L}$ and Carmona P, Structural changes of hake (Merluccius merluccius) fillets: Effects of freezing and frozen storage. J Agric Food Chem 47: 952-959.

11 Rey-Mansilla M, Sotelo C, Aubourg SP, Rehbein H, Havemeister W, JØrgensen B and Nielsen M, Localization of formaldehyde production during frozen storage of European hake (Merluccius merluccius). Eur Food Res Technol 213: 43-47 (2001).

12 Sotelo C, Piñeiro C and Pérez-Martín R, Review: Denaturation of fish proteins during frozen storage: Role of formaldehyde. Z Lebensm Unters Forsch 200, 1423 (1995).

13 Aubourg SP, Lago H, Sayar N and González R, Lipid damage during frozen storage of Gadiform species captured in different seasons. Eur J Lipid Sci Technol 109: 608-616 (2007).

14 Villamonte G, Pottier L and de Lamballerie M, Influence of high-pressure processing on the physicochemical and the emulsifying properties of sarcoplasmic proteins from hake (Merluccius merluccius). Eur Food Res Technol 242: 667-675 (2016). 
15 Cando D, Moreno H, Tovar C, Herranz B and Borderías AJ, Effect of high pressure and/or temperature over gelation of isolated hake myofibrils. Food Bioprocess Technol 7: 3197-3207 (2014).

16 Carrera M, Fidalgo L, Saraiva JA and Aubourg SP, Effects of high-pressure treatment on the muscle proteome of hake by bottom-up proteomics. J Agric Food Chem 66: 4559-4570 (2018).

17 Vidacek S, De las Heras C, Solas M, Rodríguez-Mahillo A and Tejada M, Effect of high hydrostatic pressure on mortality and allergenicity of Anisakis simplex L3 and on muscle properties of infested hake. J Sci Food Agric 89: 2228-2235. (2009).

18 Vázquez M, Fidalgo L, Saraiva J and Aubourg SP, Preservative effect of a previous high-pressure treatment on the chemical changes related to quality loss in frozen hake (Merluccius merluccius). Food Bioprocess Technol 11: 293-304 (2018).

19 Pita-Calvo C, Guerra-Rodríguez E, Saraiva JA, Aubourg SP and Vázquez M, Highpressure processing before freezing and frozen storage of European hake (Merluccius merluccius): Effect on mechanical properties and visual appearance. Eur Food Res Technol 244: 423-431 (2018).

20 Tozawa H, Erokibara K and Amano K, Proposed modification of Dyer's method for trimethylamine determination in codfish, in Fish Inspection and Quality Control, ed. by Kreuzer R. Fishing News Books Ltd, London, UK, pp. 187-190 (1971).

21 Dowden $\mathrm{H}$, The determinations of small amounts of dimethylamine in biological fluids. Biochem J 32: 455-459(1938). 
22 Nash T, The colorimetric estimation of formaldehyde by means of the Hantzsch reaction. Biochem J 55: 416-421 (1953).

23 Bligh E and Dyer W, A rapid method of total lipid extraction and purification. Can J Biochem Physiol 37: 911-917 (1959).

24 Lowry R and Tinsley I, Rapid colorimetric determination of free fatty acids. J Am Oil Chem Soc 53: 470-472 (1976).

25 Chapman R and McKay J, The estimation of peroxides in fats and oils by the ferric thiocyanate method. J Am Oil Chem Soc 26: 360-363 (1949).

26 Aubourg SP and Medina I, Influence of storage time and temperature on lipid deterioration during cod (Gadus morhua) and haddock (Melanogrammus aeglefinus) frozen storage. J Sci Food Agric 79: 1943-1948 (1999).

27 Baixas-Nogueras S, Bover-Cid S, Veciana-Nogués T, Nunes ML, Vidal-Carou MC, Development of a quality index method to evaluate freshness in Mediterranean hake (Merluccius merluccius). J Food Sci 68, 1067-1071 (2003).

28 Pazos M, Méndez L, Fidalgo L, Vázquez M, Torres A, Aubourg SP and Saraiva JA, Effect of high-pressure processing of Atlantic mackerel (Scomber scombrus) on biochemical changes during commercial frozen storage. Food Bioprocess Technol 8: 2159-2170 (2015).

29 Méndez L, Fidalgo L, Pazos M, Lavilla M, Torres JA, Saraiva JA, Vázquez M and Aubourg SP, Lipid and protein changes related to quality loss in frozen sardine (Sardina pilchardus) previously processed under high-pressure conditions. Food Bioprocess Technol 10: 296-306 (2017). 
30 Gou J, Lee HY and Ahn J, Effect of high pressure processing on the quality of squid (Todarodes pacificus) during refrigerated storage. Food Chem 119: 471-476 (2010).

31 Gou J, Choi KP, He X and Ahn J, Application of high pressure processing for extending the shelf-life of sliced raw squid. J Food Sci 75: M489-M495 (2012).

32 Malinowska-Pańczyk E and Kołodziejska I, The effect of high pressure on formation of volatile amines in minced meat of cod (Gadus morhua). Eur Food Res Technol 242: 415-420 (2016).

33 Sikorski Z and Kolakowski E, Endogenous enzyme activity and seafood quality: Influence of chilling, freezing, and other environmental factors, in: Seafood enzymes, ed. by Haard N and Simpson B. Marcel Dekker, New York, USA, pp. 451-487 (2000).

34 Torres JA, Vázquez M, Saraiva JA, Gallardo JM and Aubourg SP, Lipid damage inhibition by previous high pressure processing in white muscle of frozen horse mackerel. Eur J Lipid Sci Technol 115: 1454-1461 (2013).

35 Chevalier D, Sequeira-Muñoz A, Le Bail A, Simpson B and Ghoul M, Effect of pressure shift freezing, air-blast freezing and storage on some biochemical and physical properties of turbot (Scophthalmus maximus). Lebensm Wiss Technol 33, 570-577 (2000). 


\section{FIGURE LEGENDS}

Figure 1: Dimethylamine (DMA) formation (mg DMA-N $\cdot \mathrm{kg}^{-1}$ muscle)* in hake muscle frozen at different temperatures that was previously treated under $150 \mathrm{MPa}$ for 2 min**

* Average values of three replicates $(n=3)$; standard deviations are indicated by bars. For each frozen storage time, values accompanied by different letters (a-d) indicate significant differences $(p<0.05)$. Initial fresh value: $10.9 \pm 0.2 \mathrm{mg}$ DMA-N $\cdot \mathrm{kg}^{-1}$ muscle. Storage at $-10^{\circ} \mathrm{C}$ was only carried out up to month 9 .

** Abbreviations of samples names: CT (control sample at month 0), CT-10, CT-18 and CT-30 (control samples throughout frozen storage at $-10,-18$ and $-30{ }^{\circ} \mathrm{C}$, respectively), HPT (high-pressure treated sample at month 0), HPT-10, HPT-18 and HPT-30 (high-pressure treated samples throughout frozen storage at -10 , 18 and $-30{ }^{\circ} \mathrm{C}$, respectively).

Figure 2: Formaldehyde (FA) formation (mg. $\mathrm{kg}^{-1}$ muscle)* in hake muscle frozen at different temperatures that was previously treated under $150 \mathrm{MPa}$ for $2 \mathrm{~min} * *$

* Average values of three replicates $(n=3)$; standard deviations are indicated by bars. For each frozen storage time, values accompanied by different letters (a-d) indicate significant differences $(p<0.05)$. Initial fresh value: $0.53 \pm 0.29 \mathrm{mg}$ $\mathrm{FA} \cdot \mathrm{kg}^{-1}$ muscle. Storage at $-10{ }^{\circ} \mathrm{C}$ was only carried out up to month 9 .

** Abbreviations of samples names as expressed in Figure 1. 
Figure 3: Free fatty acid (FFA) formation (mg FFA $\mathrm{kg}^{-1}$ muscle)* in hake muscle frozen at different temperatures that was previously treated under $150 \mathrm{MPa}$ for $2 \mathrm{~min} * *$

* Average values of three replicates $(n=3)$; standard deviations are indicated by bars.

For each frozen storage time, values accompanied by different letters (a-e) indicate significant differences $(p<0.05)$. Initial fresh value: $51.65 \pm 1.49 \mathrm{mg}$ FFA $\cdot \mathrm{kg}^{-1}$ muscle. Storage at $-10^{\circ} \mathrm{C}$ was only carried out up to month 9 .

** Abbreviations of samples names as expressed in Figure 1. 


\section{TABLE 1}

Trimethylamine (TMA) assessment (mg TMA-N $\cdot \mathrm{kg}^{-1}$ muscle)* in hake muscle frozen at different temperatures that was previously treated under $150 \mathrm{MPa}$ for 2

$$
\min * *
$$

\begin{tabular}{|c|c|c|c|c|c|c|}
\hline \multirow{3}{*}{$\begin{array}{c}\text { Storage } \\
\text { time } \\
\text { (months) }\end{array}$} & \multicolumn{6}{|c|}{ Storage temperature } \\
\hline & \multicolumn{2}{|c|}{$-10^{\circ} \mathrm{C}$} & \multicolumn{2}{|c|}{$-18^{\circ} \mathrm{C}$} & \multicolumn{2}{|c|}{$-30^{\circ} \mathrm{C}$} \\
\hline & CT & HPT & & & CT & HPT \\
\hline 0 & $\begin{array}{l}1.27 \mathrm{a} \\
(0.36)\end{array}$ & $\begin{array}{l}1.26 \mathrm{a} \\
(0.06)\end{array}$ & $\begin{array}{l}1.27 \mathrm{a} \\
(0.36)\end{array}$ & $\begin{array}{l}1.26 \mathrm{a} \\
(0.06)\end{array}$ & $\begin{array}{l}1.27 \mathrm{a} \\
(0.36)\end{array}$ & $\begin{array}{l}1.26 \mathrm{a} \\
(0.06)\end{array}$ \\
\hline 3 & $\begin{array}{l}7.63 \mathrm{e} \\
(0.83)\end{array}$ & $\begin{array}{l}5.36 \mathrm{~d} \\
(0.95)\end{array}$ & $\begin{array}{l}3.45 \mathrm{c} \\
(0.53)\end{array}$ & $\begin{array}{l}1.41 \mathrm{~b} \\
(0.30)\end{array}$ & $\begin{array}{l}0.96 \mathrm{a} \\
(0.10)\end{array}$ & $\begin{array}{c}1.10 \mathrm{ab} \\
(0.11)\end{array}$ \\
\hline 6 & $\begin{array}{c}10.29 \mathrm{c} \\
(2.30)\end{array}$ & $\begin{array}{l}9.13 \mathrm{c} \\
(2.67)\end{array}$ & $\begin{array}{l}3.35 \mathrm{~b} \\
(0.39)\end{array}$ & $\begin{array}{l}1.77 \mathrm{a} \\
(0.44)\end{array}$ & $\begin{array}{l}1.33 \mathrm{a} \\
(0.53)\end{array}$ & $\begin{array}{l}2.08 \mathrm{a} \\
(0.20)\end{array}$ \\
\hline 9 & $\begin{array}{c}22.89 \mathrm{c} \\
(4.73)\end{array}$ & $\begin{array}{c}11.47 \mathrm{~b} \\
(3.18)\end{array}$ & $\begin{array}{l}4.33 \mathrm{a} \\
(1.67)\end{array}$ & $\begin{array}{l}2.88 \mathrm{a} \\
(0.44)\end{array}$ & $\begin{array}{c}2.67 \mathrm{a} \\
(0.51)\end{array}$ & $\begin{array}{c}2.98 \mathrm{a} \\
(0.47)\end{array}$ \\
\hline 12 & - & - & $\begin{array}{l}4.53 \mathrm{~b} \\
(2.15)\end{array}$ & $\begin{array}{l}3.13 \mathrm{a} \\
(0.88)\end{array}$ & $\begin{array}{l}2.68 \mathrm{a} \\
(0.71)\end{array}$ & $\begin{array}{l}3.01 \mathrm{a} \\
(0.14)\end{array}$ \\
\hline
\end{tabular}

* Average values of three replicates $(n=3)$; standard deviations are indicated in brackets. For each frozen storage time, values accompanied by different letters (a-e) indicate significant differences $(p<0.05)$. Initial fresh value: $0.88 \pm 0.21 \mathrm{mg}$ TMA-N $\cdot \mathrm{kg}^{-1}$ muscle. Storage at $-10{ }^{\circ} \mathrm{C}$ was only carried out up to month 9 .

** Abbreviations of treatments: CT (frozen fish without previous high-pressure treatment; control fish) and HPT (frozen fish with previous high-pressure treatment; pressure-treated fish). 


\section{TABLE 2}

Peroxide value assessment (meq. active oxygen $\cdot \mathrm{kg}^{-1}$ lipids)* in hake muscle frozen at different temperatures that was previously treated under 150 MPa for 2 min**

\begin{tabular}{|c|c|c|c|c|c|c|}
\hline \multirow{3}{*}{$\begin{array}{c}\text { Storage } \\
\text { time } \\
\text { (months) }\end{array}$} & \multicolumn{6}{|c|}{ Storage temperature } \\
\hline & \multicolumn{2}{|c|}{$-10^{\circ} \mathrm{C}$} & \multicolumn{2}{|c|}{$-18^{\circ} \mathrm{C}$} & \multicolumn{2}{|c|}{$-30^{\circ} \mathrm{C}$} \\
\hline & $\mathrm{CT}$ & HPT & & & $\mathrm{CT}$ & HPT \\
\hline 0 & $\begin{array}{l}3.07 \mathrm{a} \\
(0.97)\end{array}$ & $\begin{array}{l}2.97 \mathrm{a} \\
(0.60)\end{array}$ & $\begin{array}{l}3.07 \mathrm{a} \\
(0.97)\end{array}$ & $\begin{array}{l}2.97 \mathrm{a} \\
(0.60)\end{array}$ & $\begin{array}{l}3.07 \mathrm{a} \\
(0.97)\end{array}$ & $\begin{array}{l}2.97 \mathrm{a} \\
(0.60)\end{array}$ \\
\hline 3 & $\begin{array}{l}4.35 \mathrm{~b} \\
(1.11)\end{array}$ & $\begin{array}{c}4.83 \mathrm{~b} \\
(0.79)\end{array}$ & $\begin{array}{l}2.19 \mathrm{a} \\
(0.15)\end{array}$ & $\begin{array}{l}2.09 \mathrm{a} \\
(0.49)\end{array}$ & $\begin{array}{l}1.50 \mathrm{a} \\
(1.28)\end{array}$ & $\begin{array}{l}1.85 \mathrm{a} \\
(0.32)\end{array}$ \\
\hline 6 & $\begin{array}{l}5.08 \mathrm{a} \\
(0.45)\end{array}$ & $\begin{array}{l}7.08 \mathrm{~b} \\
(1.13)\end{array}$ & $\begin{array}{l}.25 \mathrm{a} \\
(0.34)\end{array}$ & $\begin{array}{l}.64 \mathrm{a} \\
(0.52)\end{array}$ & $\begin{array}{c}5.14 \mathrm{ab} \\
(0.93)\end{array}$ & $\begin{array}{l}4.93 \mathrm{a} \\
(0.96)\end{array}$ \\
\hline 9 & $\begin{array}{l}5.38 \mathrm{~b} \\
(1.54)\end{array}$ & $\begin{array}{l}5.28 \mathrm{~b} \\
(1.37)\end{array}$ & $\begin{array}{l}2.56 \mathrm{a} \\
(0.05) \\
\end{array}$ & $\begin{array}{l}3.94 \mathrm{~b} \\
(2.10) \\
\end{array}$ & $\begin{array}{c}4.13 b \\
(0.52)\end{array}$ & $\begin{array}{l}8.42 \mathrm{c} \\
(0.34)\end{array}$ \\
\hline 12 & - & - & $\begin{array}{l}3.18 \mathrm{a} \\
(0.89)\end{array}$ & $\begin{array}{l}4.72 \mathrm{~b} \\
(0.60)\end{array}$ & $\begin{array}{l}2.79 \mathrm{a} \\
(0.66)\end{array}$ & $\begin{array}{l}2.19 \mathrm{a} \\
(0.20)\end{array}$ \\
\hline
\end{tabular}

* Average values of three replicates $(n=3)$; standard deviations are indicated in brackets. For each frozen storage time, values accompanied by different letters (a-c) indicate significant differences $(p<0.05)$. Initial fresh value: $1.93 \pm 0.82$ meq. active oxygen $\cdot \mathrm{kg}^{-1}$ lipids. Storage at $-10{ }^{\circ} \mathrm{C}$ was only carried out up to month 9.

** Abbreviations of treatments as expressed in Table 1. 


\section{TABLE 3}

Fluorescence ratio evolution* in hake muscle frozen at different temperatures that was previously treated under $150 \mathrm{MPa}$ for $2 \mathrm{~min} * *$

\begin{tabular}{|c|c|c|c|c|c|c|}
\hline \multirow{3}{*}{$\begin{array}{c}\text { Storage } \\
\text { time } \\
\text { (months) }\end{array}$} & \multicolumn{6}{|c|}{ Storage temperature } \\
\hline & \multicolumn{2}{|c|}{$-10^{\circ} \mathrm{C}$} & \multicolumn{2}{|c|}{$-18^{\circ} \mathrm{C}$} & \multicolumn{2}{|c|}{$-30^{\circ} \mathrm{C}$} \\
\hline & CT & HPT & & & CT & HPT \\
\hline 0 & $\begin{array}{l}1.17 \mathrm{~b} \\
(0.06)\end{array}$ & $\begin{array}{l}0.64 \mathrm{a} \\
(0.07)\end{array}$ & $\begin{array}{l}1.17 \mathrm{~b} \\
(0.06)\end{array}$ & $\begin{array}{l}0.64 \mathrm{a} \\
(0.07)\end{array}$ & $\begin{array}{l}1.17 \mathrm{~b} \\
(0.06)\end{array}$ & $\begin{array}{l}0.64 \mathrm{a} \\
(0.07)\end{array}$ \\
\hline 3 & $\begin{array}{l}1.49 \mathrm{c} \\
(0.13)\end{array}$ & $\begin{array}{l}1.75 \mathrm{c} \\
(0.22)\end{array}$ & $\begin{array}{c}0.92 \mathrm{ab} \\
(0.42)\end{array}$ & $\begin{array}{l}0.65 \mathrm{a} \\
(0.17) \\
\end{array}$ & $\begin{array}{l}1.10 \mathrm{~b} \\
(0.13)\end{array}$ & $\begin{array}{c}0.88 \mathrm{ab} \\
(0.28)\end{array}$ \\
\hline 6 & $\begin{array}{l}1.24 \mathrm{~b} \\
(0.15)\end{array}$ & $\begin{array}{c}1.25 \mathrm{ab} \\
(0.36)\end{array}$ & $\begin{array}{c}1.16 \mathrm{ab} \\
(0.65)\end{array}$ & $\begin{array}{c}1.33 \mathrm{ab} \\
(0.43)\end{array}$ & $\begin{array}{l}0.85 \mathrm{a} \\
(0.14)\end{array}$ & $\begin{array}{c}0.78 \mathrm{a} \\
(0.18)\end{array}$ \\
\hline 9 & $\begin{array}{l}1.38 \mathrm{~b} \\
(0.39)\end{array}$ & $\begin{array}{l}0.81 \mathrm{a} \\
(0.02)\end{array}$ & $\begin{array}{c}1.17 \mathrm{ab} \\
(0.29)\end{array}$ & $\begin{array}{l}0.86 \mathrm{a} \\
(0.09)\end{array}$ & $\begin{array}{c}0.99 \mathrm{ab} \\
(0.22)\end{array}$ & $\begin{array}{l}0.68 \mathrm{a} \\
(0.09)\end{array}$ \\
\hline 12 & - & - & $\begin{array}{l}0.87 \mathrm{a} \\
(0.11)\end{array}$ & $\begin{array}{l}0.94 \mathrm{a} \\
(0.26)\end{array}$ & $\begin{array}{l}0.92 \mathrm{a} \\
(0.13)\end{array}$ & $\begin{array}{l}0.89 \mathrm{a} \\
(0.07)\end{array}$ \\
\hline
\end{tabular}

* Average values of three replicates $(n=3)$; standard deviations are indicated in brackets. For each frozen storage time, values accompanied by different letters (a-c) indicate significant differences $(p<0.05)$. Initial fresh value: $0.88 \pm 0.08$. Storage at $-10^{\circ} \mathrm{C}$ was only carried out up to month 9 .

** Abbreviations of treatments as expressed in Table 1. 

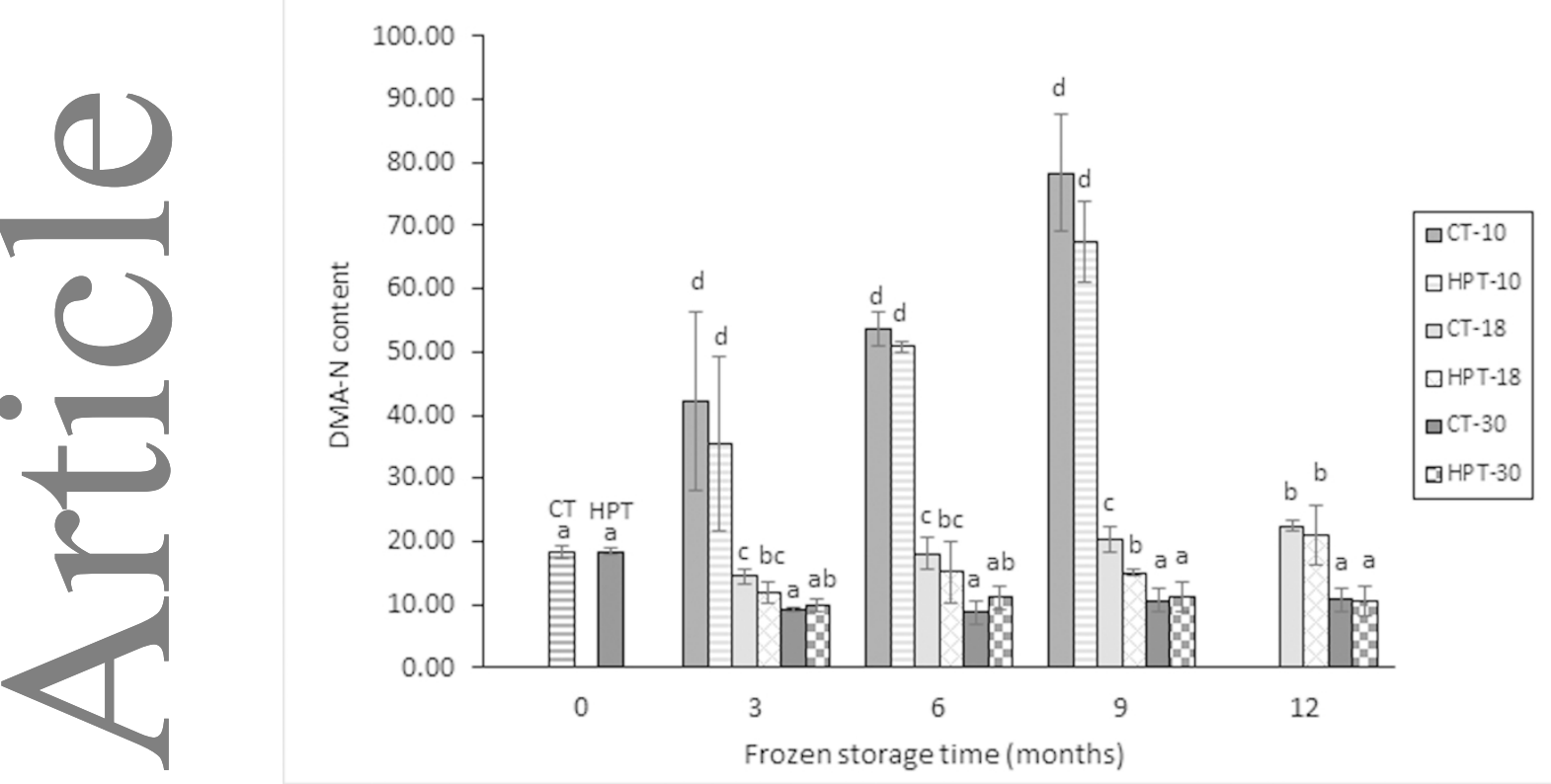

This article is protected by copyright. All rights reserved. 


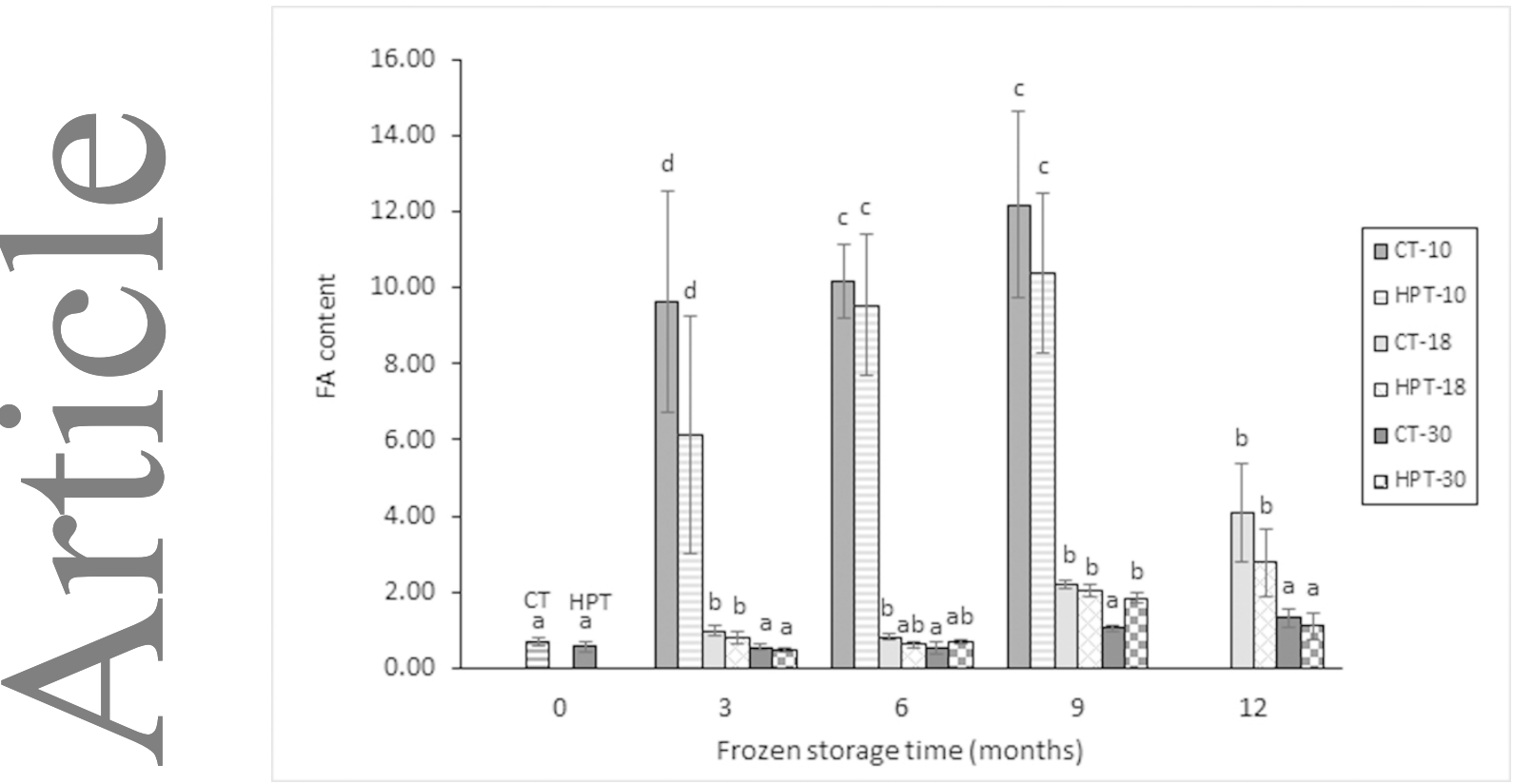

This article is protected by copyright. All rights reserved. 


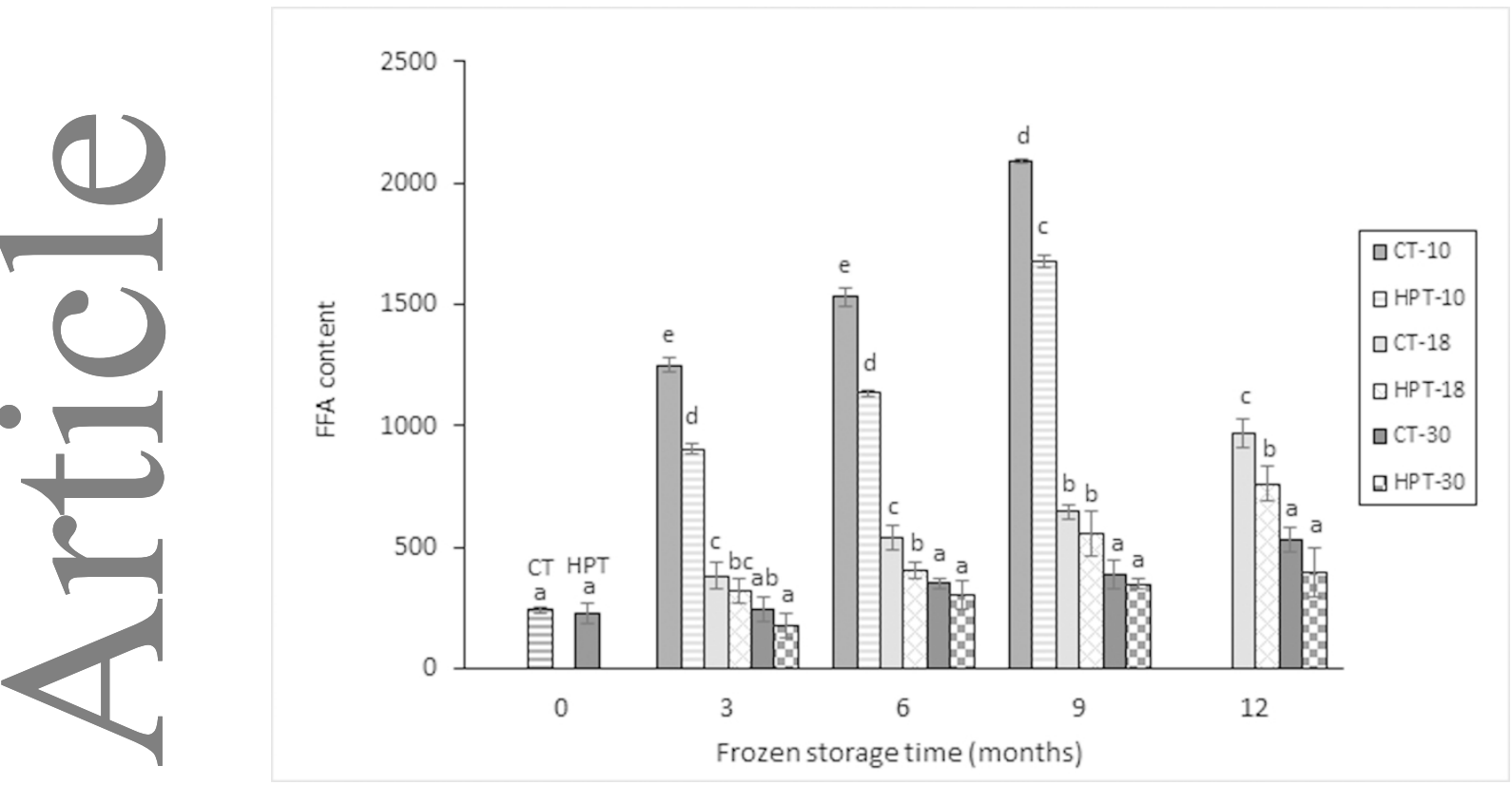

This article is protected by copyright. All rights reserved. 